\title{
Titán-dioxid-nanopálcikák tüdőre kifejtett hatásának állatkísérletes vizsgálata szubakut patkánymodellben
}

\author{
Horváth Tamara $^{1}$ - Papp András dr. ${ }^{1}$ - Kiricsi Mónika dr. ${ }^{2}$ \\ Igaz Nóra ${ }^{2}$ - Trenka Vivien ${ }^{2}$ - Kozma Gábor dr. ${ }^{3}$ - Tiszlavicz László dr. ${ }^{4}$ \\ Rázga Zsolt dr. ${ }^{4}$. Vezér Tünde dr. ${ }^{1}$
}

\begin{abstract}
Szegedi Tudományegyetem, 'Általános Orvostudományi Kar, Népegészségtani Intézet, ${ }^{2}$ Természettudományi és Informatikai Kar, Biokémiai és Molekuláris Biológiai Tanszék, ${ }^{3}$ Természettudományi és Informatikai Kar, Alkalmazott és Környezeti Kémiai Tanszék, ${ }^{4}$ Általános Orvostudományi Kar, Patológiai Intézet, Szeged
\end{abstract}

\begin{abstract}
Bevezetés: Napjainkban a nanotechnológia intenzív terjedésével nő a munkahelyi és lakossági nanorészecske-expozíció veszélye. Jelenleg azonban kevés tudományosan megalapozott, ellentmondásmentes ismeret áll rendelkezésre a nehézfém nanorészecskék toxicitásáról és potenciális egészségkárosító hatásairól.

Célkitüzés: Szubakut, intratrachealisan instillált, pálcika alakú titán-dioxid $\left(\mathrm{TiO}_{2}\right)$-nanorészecskék indukálta tüdőszövet-károsodás vizsgálata morfológiai, kémiai és biokémiai módszerekkel, patkánymodellben.

Módszer: Az általános toxicitást (test- és szervtömegváltozás), a lokális (alveolaris üregekben/epithelben, hilusi nyirokcsomóban zajló) akut és krónikus celluláris toxicitást (gyulladás, sejtpusztulás), továbbá az oxidatív stresszt fényés elektronmikroszkópiával, valamint biokémiai (lipidperoxidáció, reaktívoxigén-gyök, proinflammatoricus citokin expressziója) úton mértük.

Eredmények: A kezelt csoportok testtömegében dózis- és időfüggő eltérés nem volt, azonban a tüdők tömege és Titartalma a dózissal arányosan nőtt. A tüdőszövet fény- és elektronmikroszkópos vizsgálata igazolta a nanorészecskék jelenlétét az alveolaris térben szabadon és az alveolaris epitheltől független macrophagok phagosomáiban. A lokális akut alveolitis krónikussá válását alátámasztotta az alveolaris régió macrophagszámának dózisfüggő növekedése, az interstitium ödémája és megvastagodása, valamint egyes proinflammatoricus citokinek (interleukin-la, LIX, L-szelektin, vascularis endothelialis növekedési faktor) fokozott expressziója. A kezelt állatok tüdőszövetében az oxidatív stressz és a lipidperoxidáció jelentősen fokozódott. A kezelt tüdők tömege, Ti-tartalma és a lipidperoxidáció mértéke között korrelációt találtunk. Az alveolaris epithel-capillaris endothel barrier elégtelenségére utaltak a nanorészecskékkel telt falósejtek a hilusi nyirokcsomóban, ami felveti a nanorészecskék szisztémás keringésbe és távolabbi szervekbe jutásának és akut szisztémás gyulladás kialakulásának lehetőségét.

Következtetés: $\mathrm{Az}$ alsó légutakba jutott $\mathrm{TiO}_{2}$-nanorészecskék etiológiai tényezóként szerepelhetnek az akut, illetve idült légúti gyulladással és/vagy progrediáló fibrosissal és obstrukcióval járó légzőszervi betegségek (például idült obstruktív tüdőbetegség, asztma) kialakulásában és/vagy progressziójában, melyben jelentősége lehet az autophagiának és az immunválasz (lymphocytamúködés) károsodásának.
\end{abstract}

Orv Hetil. 2019; 160(2): 57-66.

Kulcsszavak: titán-dioxid, nanorészecske, patkány, oxidatív stressz, citokin, patológia

\section{Investigation of the effect of titanium dioxide nanorods on the lungs in a subacute rat model}

Introduction: The development of nanotechnology increases the risk of occupational and population-level exposure to nanoparticles nowadays. However, scientifically based knowledge relating to the toxicity of heavy metal nanoparticles and potential health damage is insufficient.

Aim: Investigation of lung tissue damage induced by titanium dioxide $\left(\mathrm{TiO}_{2}\right)$ nanorods in subacute intratracheal instillation by morphological, chemical and biochemical methods in rat model. 
Method: General toxicity (changes of body and organ weights), local acute and chronic cellular toxicity (in alveolar spaces and epithelium, in hilar lymph nodes) and oxidative stress were examined using light and electron microscopy, and biochemical methods (reactive oxygen species, lipid peroxidation, expression of pro-inflammatory cytokines). Results: No dose- and time-dependent alteration was found in the body weight of the treated groups; but the mass and $\mathrm{Ti}$ content of lungs increased with dose. Light and electron microscopy of the lung tissue verified the presence of nanoparticles, free in the alveolar space and within phagosomes of macrophages not attached to alveolar epithelium. Chronification of local acute alveolitis was supported by dose-dependent increase of macrophage count in the alveolar region, oedema and thickening of interstitium, and increased expression of certain pro-inflammatory cytokines (interleukin-1 $a$, LIX, L-selectin, vascular endothelial growth factor). Oxidative stress and lipid peroxidation increased substantially in the treated rats' lungs, and correlation was found between Ti content and lipid peroxidation. Insufficiency of the alveolar epithelial and capillary endothelial barrier was indicated by nanoparticle-laden phagocytes in hilar lymph nodes, suggesting nanoparticles reaching systemic circulation and distant organs, inducing systemic acute inflammation.

Conclusion: $\mathrm{TiO}_{2}$ nanoparticles, reaching lower airways, may be etiological factors in the causation or aggravation of pulmonary diseases with acute and chronic airways inflammation and/or progressive fibrosis and obstruction (e.g., chronic obstructive pulmonary disease or asthma). Autophagy and damaged immune response (lymphocytic activity) may have here a role.

Keywords: titanium dioxide, nanoparticles, rat, oxidative stress, cytokines, pathology

Horváth T, Papp A, Kiricsi M, Igaz N, Trenka V, Kozma G, Tiszlavicz L, Rázga Zs, Vezér T. [Investigation of the effect of titanium dioxide nanorods on the lungs in a subacute rat model]. Orv Hetil. 2019; 160(2): 57-66.

(Beérkezett: 2018. július 4.; elfogadva: 2018. augusztus 14.)

\begin{abstract}
Rövidítések
ANOVA $=($ analysis of variance $)$ varianciaanalízis; ÁOK $=$ Általános Orvostudományi Kar; $\mathrm{CINCl}=$ (cytokine-induced neutrophil chemoattractant-1) citokin indukálta neutrofil kemoattraktáns- 1 COPD $=$ (chronic obstructive pulmonary disease $)$ idült obstruktív tüdőbetegség; DLS = (dynamic light scattering) dinamikus fényszórás; GLP $=$ (good laboratory practice $)$ helyes laboratóriumi gyakorlat; $\mathrm{HE}=$ hematoxilin-eozin; ICPMS = (inductively coupled plasma mass spectrometry) induktív csatolású plazma-tömegspektrometria; IL = interleukin; MDA $=$ malondialdehid $; \mathrm{NP}=$ (nanoparticle $)$ nanopartikulum, nanorészecske; $\mathrm{PAA}=$ poliakrilsav $\mathrm{PEF}=($ peak expiratory flow $)$ kilégzési csúcsáramlás; ROS $=$ (reactive oxygen species) reaktívoxigén-gyök; $S P F=$ (specified pathogen free) specifikált patogénektől mentes; SZTE = Szegedi Tudományegyetem; TBARS $=($ thiobarbituric acid reactive substances $)$ tiobarbiturátreaktív anyagok; TEM = transzmissziós elektronmikroszkóp; $\mathrm{TiO}_{2}=$ titán-dioxid; TTIK = Természettudományi és Informatikai Kar; VEGF $=$ (vascular endothelial growth factor) vascularis endothelialis növekedési faktor
\end{abstract}

A nanotechnológia folyamatos fejlődésével egyre több iparágban és termékben fordulnak elő nanopartikulumok (NP-ok, azaz legalább az egyik dimenzióban 100 nm-nél nem nagyobb szemcsék, pálcikák, csövecskék stb.). Újszerú gyógyszerformák, antibakteriális anyagok és felületi bevonatok, fényvédő kozmetikumok, étrendkiegészítők, elektronikai termékek említhetók példaként. Mindezek eredményeképpen egyre gyakoribb a nanoanyagokkal történő humánexpozíció [1,2]. Mivel a NPok fizikai, kémiai, valamint (ezekből következő) biológiai tulajdonságai nagyon eltéróek lehetnek más anyagoké- ihoz vagy akár a nanoszemcsét alkotó vegyület megszokott halmazállapotához képest [3], az élő szervezettel való kölcsönhatásaik, így toxikológiai tulajdonságaik is még csak részlegesen ismertek, ami egy újszerú egészségi kockázat lehetőségére [4] és ennélfogva az egészségvédelmi intézkedéseket alátámasztó kutatások szükségességére [5] mutat rá. A humánmedicinában is terjedőben van a nanotechnológia, ami a kedvező hatások mellett eddig nem ismert kockázatok felszínre kerülését jelentheti. Ezen a területen elsősorban dermalis és inhalációs expozícióval kell számolni, de várhatóan egyre elterjedtebb lesz az intravénás hatóanyagok, illetve implantátumok útján történő expozíció is [6]. A termékekben, a szándékos alkalmazásokban való előforduláson túl, a mikro- és makrokörnyezetbe kikerült NP-ok legnagyobb valószínúséggel az atmoszférában lesznek megtalálhatók, igen stabil aeroszol formájában [1], ami még hangsúlyosabbá teszi a légúti expozíció jelentőségét.

A titán-dioxidnak $\left(\mathrm{TiO}_{2}\right)$ több ismert ipari alkalmazása van, a legjelentősebb a fehér pigmentként történő felhasználása nemcsak festékekben, hanem élelmiszer- és gyógyszeripari színező- és bevonóanyagokban is. Ezen túlmenően a fogkrémek, a bőrápolási termékek és (különösen) a magas fényvédő faktorú kozmetikai (napvédő) szerek szintén gyakran tartalmaznak nano- $\mathrm{TiO}_{2}$-ot [7]. A $\mathrm{TiO}_{2}$ anatáz formája fotokatalitikus tulajdonsággal rendelkezik, ezért adalékanyagként alkalmazzák például „öntisztuló” festékek és építőanyagok elóállításakor [8].

A $\mathrm{TiO}_{2}$-NP-ok egyre szélesebb körben és növekvő mértékben történő alkalmazása a fentiek értelmében (például a termékeket elő́llító munkavállalók és/vagy a 
felhasználók körében) egészségi kockázatot jelenthet, melynek mértéke azonban tisztázatlan. Jelenleg ellentmondásos irodalmi adatok állnak rendelkezésre mind a nano- $\mathrm{TiO}_{2}$ dermalis és pulmonalis abszorpciója, mind pedig biológiai hatásai tekintetében [9], és hasonló a helyzet a klinikai alkalmazásokkal kapcsolatban is [6]. A részecskék krónikus (akár több mint 20 évig tartó) belégzésével összefüggően az exponált dolgozók tüdőrákkockázata egyes (több országot átfogó) vizsgálatok szerint fokozott [10], míg mások ilyen összefüggést sem humán populációban $[11,12]$, sem állatkísérletben (hasonló aeroszollal kezelt patkányok esetében) [13] nem találtak.

Ismert azonban a múltban előfordult munkahelyi $\mathrm{TiO}_{2}$-nanopor-terhelésből eredő csökkent légzési kapacitás és pleuramegvastagodás [14]. Állatkísérletben már egyetlen belélegeztetett $\mathrm{TiO}_{2}$-NP-dózis a macrophagok aktiválódását [15] és a citokinek fokozott termelését [16] idézte elő. A citokintermelés szoros kapcsolatban áll az autophagiával mint a sejten belülre került idegen anyagok eliminációjának módjával [17] - a bekebelezett NP-ok azonban enzimesen többnyire nem bonthatók le, miáltal a phagosomák normális feldolgozása megakad, továbbá a lysosomák megsérülő membránja hidrolitikus enzimeket, vasat stb. bocsát a citoplazmába. Az előbbi folyamat az autophagiát állítja át a sejtet megvédő helyett azt elpusztító múködésre, az utóbbi pedig oxidatív stressz és mitokondriumkárosodás útján vezethet gyulladásos reakcióhoz, illetve apoptotikus sejthalálhoz. A lysosomák destabilizációját nano- $\mathrm{TiO}_{2}$-dal kezelt sejtkultúrákban is kimutatták [18].

A humán légúti expozíciót és károsodást modellező állatkísérletek többségét gömbszerü NP-okkal végezték, azonban több nagy gyakorlati jelentőségű alkalmazásban (immunterápia [19], biokompatibilis implantátumok [20], antimikrobiális textíliák [21]) a nanopálcikák, -csövecskék stb. előnyösebbek. Ezek viszont, méretüknél és alakjuknál fogva, a macrophagok számára nem kebelezhetők be, és úgynevezett „frusztrált” phagocytosist idéznek elő (akadályozva a falósejtek múködését), ami fokozott intracelluláris ROS-termeléshez, -akkumulációhoz, ennek következtében oxidatív stresszhez, továbbá a lysosomák sérülése által proinflammatoricus citokinek kibocsátásához, a membránpermeabilitás fokozódásához, cytoskeletalis dezorganizációhoz, végül pedig sejthalálhoz vezet [22].

\section{Célkitüzés}

A fentieket szem előtt tartva, a jelen munkában szubakut intratrachealis adagolással kezeltünk fiatal felnőtt hím patkányokat pálcika formájú $\mathrm{TiO}_{2}-\mathrm{NP}$-okkal. Vizsgáltuk a $\mathrm{TiO}_{2}-\mathrm{NP}$ alsó légutakba jutását és az általa indukált általános toxikológiai (például test-, illetve szervtömegekben megnyilvánuló) hatásokat, továbbá a lokális szervspecifikus toxicitást, így a célszervben - tüdő alveolaris régió - megfigyelhető patológiai, kémiai és oxidatív stresszre utaló biokémiai változásokat. Megvizsgáltuk továbbá a nano-Ti indukálta lokális gyulladásos folyamatok szisztémássá válásának lehetőségét is.

\section{Anyagok és módszer}

\section{Állatok és kezelésük}

A kísérletben specifikált patogénektől mentes (specified pathogen free, SPF) higiénés statusú, 6 hetes, $210 \pm 5 \mathrm{~g}$ kezdő testtömegű fiatal felnőtt hím Wistar (Crl: WI BR) patkányokat (Toxi-Coop Zrt., Balatonfüred) használtunk. Az összesen 50 állatot random módon 5 csoportba soroltuk (10 állat/csoport), majd 2 napig akklimatizáltuk. Ez a csoportonkénti elemszám előzetes erőanalízis (power analysis) alapján ( $\mathrm{p}=0,8$ esetén) elegendően nagynak bizonyult. A kísérlet alatt standard állatházi körülményeket biztosítottunk $\left(22 \pm 3{ }^{\circ} \mathrm{C}, 30-70 \%\right.$ páratartalom, 12 órás fény/sötétség ciklus). A vizsgálatokat a „helyes laboratóriumi gyakorlat” (good laboratory practice, GLP) minőségbiztosítási elveinek megfelelő körülmények között, érvényes állatkísérleti engedély (XXI/153/2013. sz.) birtokában folytattuk le.

Az akklimatizációt követő 28 napos kezelés (5 kezelési nap/hét) során az 5 közül 3 csoportnak naponta 1 alkalommal 8 és 10 óra között, az 1. táblázat szerinti dózisú nano- $\mathrm{TiO}_{2}$-szuszpenziót instilláltunk intratrachealisan, rövid dietil-éteres bódításban [23]. Az állatok testtömegét naponta mértük, ami alapját képezte a napi kezelési térfogatok, továbbá a csoportonkénti testtömegátlagok, a hetenkénti változások és a súlygyarapodási ütem meghatározásának. A nanoanyagot a SZTE Alkalmazott és Környezeti Kémiai Tanszéken állították elő. A körülbelül $15 \times 65 \mathrm{~nm}$ méretű, pálcikaszerű NP-okat 1\% poliakrilsavat (PAA) tartalmazó foszfátpufferelt fiziológiás sóoldatban szuszpendáltuk. A nanoszuszpenzió stabilitását a dinamikus fényszórás (dynamic light scattering, DLS) módszerével vizsgáltuk, frissen előállított és 4 hó-

1. táblázat |Az instillatióval kezelt kontroll- és $\mathrm{TiO}_{2}$-NP-exponált csoportok és az alkalmazott nano- $\mathrm{TiO}_{2}$-dózisok

\begin{tabular}{|c|c|c|c|c|c|}
\hline Csoportok & Kontroll & Vivőanyagos kontroll & Kis dózis & Közepes dózis & Nagy dózis \\
\hline Kezelés & $0,9 \% \mathrm{NaCl}$ & $1 \% \mathrm{PAA}$ & $\begin{array}{l}5 \mathrm{mg} / \mathrm{ttkg} \\
\mathrm{TiO}_{2}-\mathrm{NP}\end{array}$ & $\begin{array}{l}10 \mathrm{mg} / \mathrm{ttkg} \\
\mathrm{TiO}_{2}-\mathrm{NP}\end{array}$ & $\begin{array}{l}18 \mathrm{mg} / \mathrm{ttkg} \\
\mathrm{TiO}_{2}-\mathrm{NP}\end{array}$ \\
\hline
\end{tabular}

$\mathrm{PAA}=$ poliakrilsav; $\mathrm{TiO}_{2}-\mathrm{NP}=$ titán-dioxid-nanorészecske 
napig szobahőmérsékleten tárolt nanoszuszpenzió részecskeméret-eloszlásának összehasonlításával. A szuszpenzió intratrachealis beadási térfogata $1 \mathrm{ml} / \mathrm{ttkg}$ volt. A vivőanyagos kontrollcsoport ezt a közeget kapta, NPtartalom nélkül (1. táblázat).

\section{Autopszia és szövetminta-pételezés}

A 28. kezelési napot követően az állatokat (uretántúladagolással) kíméletes terminális narkózisban részesítettük. Az utolsó légvétel után megnyitottuk a mellkast, majd transcardialis perfúziót végeztünk $300 \mathrm{ml}, 4^{\circ} \mathrm{C}$-ra hütött fiziológiás sóoldattal, a szervek vértelenítése céljából. Az autopszia során mértük a szervek (szív, vesék, mellékvesék, máj, tüdő, lép, csecsemőmirigy) abszolút tömegét, és kiszámítottuk az (1/100 testtömegre, illetve agytömegre vonatkoztatott) relatív szervtömegeket. Az állatok jobb tüdőfelét folyékony nitrogénben lefagyasztottuk, majd $-20{ }^{\circ} \mathrm{C}$-on tároltuk kémiai és biokémiai mérésekhez, míg a bal tüdőfelüket $4 \%$-os formalinoldatban fixáltuk a patológiai vizsgálatok céljából történő általános (hematoxilin-eozin, HE) szövettani festésig.

\section{Analitikai és kórszövettani vizsgálatok}

Az elemi Ti tüdőmintákban lévő teljes koncentrációjának meghatározása a SZTE Szervetlen és Analitikai Kémiai Tanszékén történt, induktív csatolású plazma-tömegspektrometria (ICP-MS, kvantitatív elemanalitikai módszer) alkalmazásával, savas $\left(\mathrm{HNO}_{3}+\mathrm{HCl}\right)$ roncsolást követően [24, 25].

A biokémiai vizsgálatok elsősorban az alsó légúti alveolaris régió celluláris (alveolaris epithel, macrophag) szintü károsodásainak (akut/krónikus gyulladás, sejtpusztulás) detektálására fókuszáltak. A patkányok tüdőszövetében a proinflammatoricus fehérjék expresszióját 'multiplex cytokine assay'-vel (29 kemokin és citokin, Bio-Techne, Minneapolis, MN, Amerikai Egyesült Államok [USA]) detektáltuk. A $\mathrm{TiO}_{2}$-kezelés következtében túltermelt reaktívoxigén-gyökök (ROS) miatt kialakuló oxidatív stressz és lipidperoxidáció mérésére a katalázaktivitás mérése és a tiobarbituráttal reagáló malondialdehid (MDA) kimutatása történt tüdőszövet-lizátumban.

A lipidperoxidáció mértékét a tüdőszövet-lizátumban tiobarbiturátreakcióval (TBARS) határoztuk meg [26], a kataláz aktivitását pedig a minták $\mathrm{H}_{2} \mathrm{O}_{2}$-bontó képessége alapján mértük (Bergmayer-egységben: $1 \mathrm{BE}=1 \mathrm{~g} \mathrm{H}_{2} \mathrm{O}_{2}$ lebontása percenként, $25^{\circ} \mathrm{C}$-on) [27]. Mindkét értéket a minta Bradford-módszerrel meghatározott fehérjetartalmára vonatkoztatva adtuk meg. A biokémiai mérések a SZTE TTIK Biokémiai és Molekuláris Biológiai Tanszékén történtek.

A SZTE ÁOK Patológiai Intézetében végzett fénymikroszkópos szövettani vizsgálathoz minden egyes állat formalinfixált bal tüdőfeléből $3 \mu \mathrm{m}$ vastagságú, hematoxilin-eozin (HE) festésű metszetek készültek. A metszetek digitális képeinek kvantitatív kiértékelése az ImageJ szoftverrel [28] történt. A mérettartomány kalibrálását és validálását követően a metszet egész területén, a nano$\mathrm{TiO}_{2}$-ot fagocitált macrophagok manuális megjelölésével, a program automatikusan megadta (a metszet teljes területére eső) macrophagszámot, azok legnagyobb átmérőjét és az általuk a metszeten képviselt összes területet. A transzmissziós elektronmikroszkópos (TEM-) felvételekhez a szövetmintákból, múgyantába beágyazva, 70 nm-es metszetek készültek urán-ólom festéssel.

\section{Statisztika}

A vizsgálati eredmények normáleloszlását KolmogorovSzmirnov-teszt segítségével ellenőriztük. Normáleloszlás esetén parametrikus egyutas ANOVA fö- és post hoc Tukey-tesztet, nem normáleloszlás esetén Kruskal-Wallis fö- és post hoc Mann-Whitney-féle U-analízist végeztünk. A statisztikai értékelés SPSS 24.0 verziójú (IBM Corporation, Armonk, NJ, USA) programmal történt. A csoportok közti eltéréseket $\mathrm{p}<0,05$ esetén tekintettük szignifikánsnak.

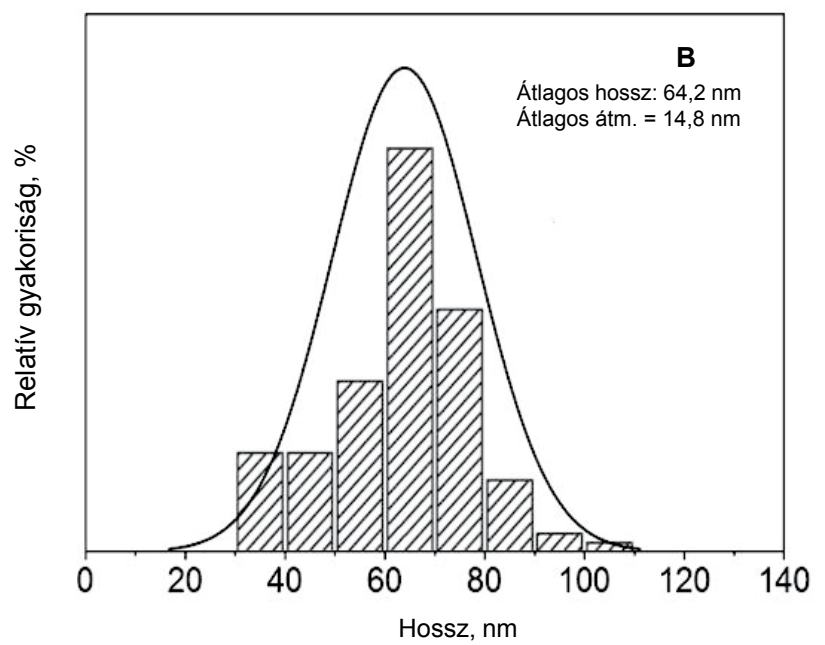

1. ábra |A vivőanyagban szuszpendált $\mathrm{TiO}_{2}$-nanopálcikák méreteloszlása friss állapotban (A) és 4 hónapos tárolás után (B) 
Az állatok testtömege a kezelési idő végén, valamint a relatív tüdőtömeg ( $1 \mathrm{~g} / 100 \mathrm{~g}$ testtömeg)

\begin{tabular}{|c|c|c|c|}
\hline $\begin{array}{l}\text { Kezelési } \\
\text { csoportok }\end{array}$ & $\begin{array}{l}\text { Intratrachealis } \\
\text { kezelések }\end{array}$ & $\begin{array}{l}\text { Testtömeg }(\mathrm{g}) \\
\text { a kísérlet végén }\end{array}$ & $\begin{array}{l}\text { Relatív } \\
\text { tüdötömeg }\end{array}$ \\
\hline Kontroll & $0,9 \mathrm{NaCl}$ & $355,5 \pm 32,62$ & $1,05 \pm 0,44$ \\
\hline $\begin{array}{l}\text { Vivóanyagos } \\
\text { kontroll }\end{array}$ & $1 \%$ PAA & $356,2 \pm 26,65$ & $1,24 \pm 0,57$ \\
\hline Kis dózis & $\begin{array}{l}5 \mathrm{mg} / \mathrm{ttkg} \\
\mathrm{TiO}_{2}-\mathrm{NP}\end{array}$ & $355,0 \pm 29,75$ & $1,37 \pm 0,26$ \\
\hline Közepes dózis & $\begin{array}{l}10 \mathrm{mg} / \mathrm{ttkg} \\
\mathrm{TiO}_{2}-\mathrm{NP}\end{array}$ & $350,8 \pm 18,59$ & $1,52 \pm 0,51$ \\
\hline Nagy dózis & $\begin{array}{l}18 \mathrm{mg} / \mathrm{ttkg} \\
\mathrm{TiO}_{2}-\mathrm{NP}\end{array}$ & $354,4 \pm 14,48$ & $1,74 \pm 0,19^{* * \# \#}$ \\
\hline
\end{tabular}

Átlag \pm szórás, $\mathrm{n}=10$

${ }^{* *} \mathrm{p}<0,01$ vs. kontroll

\#\# $\mathrm{p}<0,01$ vs. vivőanyagos kontroll

$\mathrm{n}$ = állatszám/csoport $; \mathrm{PAA}=$ poliakrilsav; $\mathrm{TiO}_{2}-\mathrm{NP}=$ titán-dioxidnanorészecske

\section{Eredmények}

A DLS-eredmények alátámasztották, hogy az 1\% PAA mint stabilizátor felhasználásával készült, pálcika alakú $\mathrm{TiO}_{2}$-NP-ok körülbelül $15 \times 65 \mathrm{~nm}$ nagyságúak, és az elóállított nanoszuszpenzió hosszú időintervallumban stabil marad (1. ábra). A kísérlet során a 28 napos $\mathrm{TiO}_{2}$ NP-adagolással összefüggő klinikai tüneteket vagy elhullást nem tapasztaltunk a csoportokban. Az állatok testtömegváltozásának mértékében, illetve ütemében megnyilvánuló általános toxikus hatás sem volt megfigyelhető, így valamennyi csoportban az életkor előrehaladásával folyamatos testtömeg-növekedést mértünk. A kezelés végén a testtömeg 100 g-jára vonatkoztatott $1 \mathrm{~g}$ relatív szervtömegek közül csupán a $18 \mathrm{mg} /$ ttkg $\mathrm{TiO}_{2}{ }^{-}$ NP-kezelt csoportban volt megfigyelhető a tüdők és a vesék (nem látható adat) szignifikáns dózisfüggő növekedése - azzal együtt is, hogy a tüdő tömegére magának a kezelési eljárásnak is volt hatása, amit a kontroll- és vivőanyagos kontrollcsoportok relatív tüdőtömegének eltérése jelez (2. táblázat).

A 28 napos intratrachealis expozíciót követően a nano- $\mathrm{TiO}_{2}$-kezelt állatok tüdőmintáiban az ICP-MS módszerrel mért összes Ti-koncentráció mindkét kontrollcsoporthoz képest szignifikánsan magasabb értéket mutatott (3. táblázat). A fiziológiás sóoldattal, illetve 1\% PAA-val kezelt kontrollok tüdőmintáiban kimutatott igen alacsony elemi Ti-szint néhány állat véletlenszerü keresztkontaminációjából adódhatott, mivel az ezekbe a csoportokba tartozó patkányok tüdőszövetmintájában $\mathrm{TiO}_{2}$-NP-ot fagocitált macrophag nem volt detektálható. Ezekből az következik, hogy a $\mathrm{TiO}_{2}-\mathrm{NP}$-exponált patkányok tüdőszövetében mért fémkoncentráció elsősorban a légutakba instillált és annak distalis szakaszáig (alveolaris régió) eljutott $\mathrm{TiO}_{2}$-nanopálcikák jelenlétéből adódott. Ez arra utal, hogy az intratrachealisan bejuttatott $15 \times 65 \mathrm{~nm}$ nagyságú, pálcika alakú NP-ok a trachea és a bronchusok falán nem tapadtak meg, hanem méretüknél fogva az alsó légutakig eljutottak, és az alveolusüregekben akkumulálódtak. Ezt alátámasztják a kezelt állatok tüdőmetszetéból készült elektron-, illetve HEfestett fénymikroszkópos felvételek is. A fénymikroszkópos képeken a sötéten festődo, szabadon álló NP-szemcsékkel telt alveolusüregek és a NP-okat már bekebelezett, az alveolaris epithel falától független macrophagok (2/ $C-E$ ábra), míg az elektronmikroszkópos felvételeken, a macrophagok plazmájában, nanopálcikákkal tömött phagosomák láthatók $(3 / B-E$ ábra). Ugyanakkor a TEMfelvételek azt is alátámasztják, hogy a NP-ok nemcsak az alveolaris üregekbe, hanem az interstitiumba is bejutottak, mivel NP-ok több száz nm-es konglomerátumai az alveolaris és interstitialis helyzetű macrophagok multive-

3. táblázat |A tüdőminták Ti-szintje és a $\mathrm{TiO}_{2}$-NP-tartalmú macrophagok száma HE-festett tüdőszövetmetszetekben

\begin{tabular}{|c|c|c|c|c|}
\hline \multirow[t]{2}{*}{ Kezelési csoportok } & \multirow{2}{*}{$\begin{array}{l}\text { A tüdőszövet Ti-szintje } \\
(\mathrm{mg} / \mathrm{kg})\end{array}$} & \multicolumn{3}{|c|}{ A $\mathrm{TiO}_{2}$-NP-tartalmú macrophagok száma a HE-festett tüdőszövetmetszetekben } \\
\hline & & Szám & Összátmérő & Összesített terület \\
\hline Kontroll & $4,16 \pm 4,12$ & n.d. & - & - \\
\hline Vivőanyagos kontroll & $2,26 \pm 1,84$ & n.d. & - & - \\
\hline Kis dózis & $207,20 \pm 72,85^{* * \# \#}$ & 179 & $34,90 \pm 5,18$ & $133798 \pm 69733^{* * \# \# \#}$ \\
\hline Közepes dózis & $191,19 \pm 72,85^{* * \# \#}$ & 192 & $40,70 \pm 6,97$ & 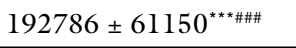 \\
\hline Nagy dózis & $610,44 \pm 133,03^{* * \# \#}$ & 265 & $43,00 \pm 5,76$ & $314682 \pm 129890^{* * * \# \# \#^{\circ \circ}}$ \\
\hline
\end{tabular}

Átlag \pm szórás, $\mathrm{n}=10$

${ }^{* *},{ }^{* * *} \mathrm{p}<0,01 ; 0,001$ vs. kontroll

\#\#, \#\#\# $\mathrm{p}<0,01 ; 0,001$ vs. vivőanyagos kontroll

${ }^{\circ} \mathrm{p}<0,01$ vs. kis dózis

$\mathrm{HE}=$ hematoxilin-eozin festés; $\mathrm{n}$ = állatszám/csoport; $\mathrm{n} . \mathrm{d} .=$ nem detektálható; $\mathrm{TiO}_{2}-\mathrm{NP}=$ titán-dioxid-nanorészecske; Ti-szint = az egységnyi szövetmintában ICP-MS módszerrel mért teljes Ti-koncentráció

A macrophagok számának meghatározása a HE-festett tüdőszövetmetszetek fénymikroszkópos vizsgálata alapján (nagyítás: 10×) ImageJ analízissel történt. 

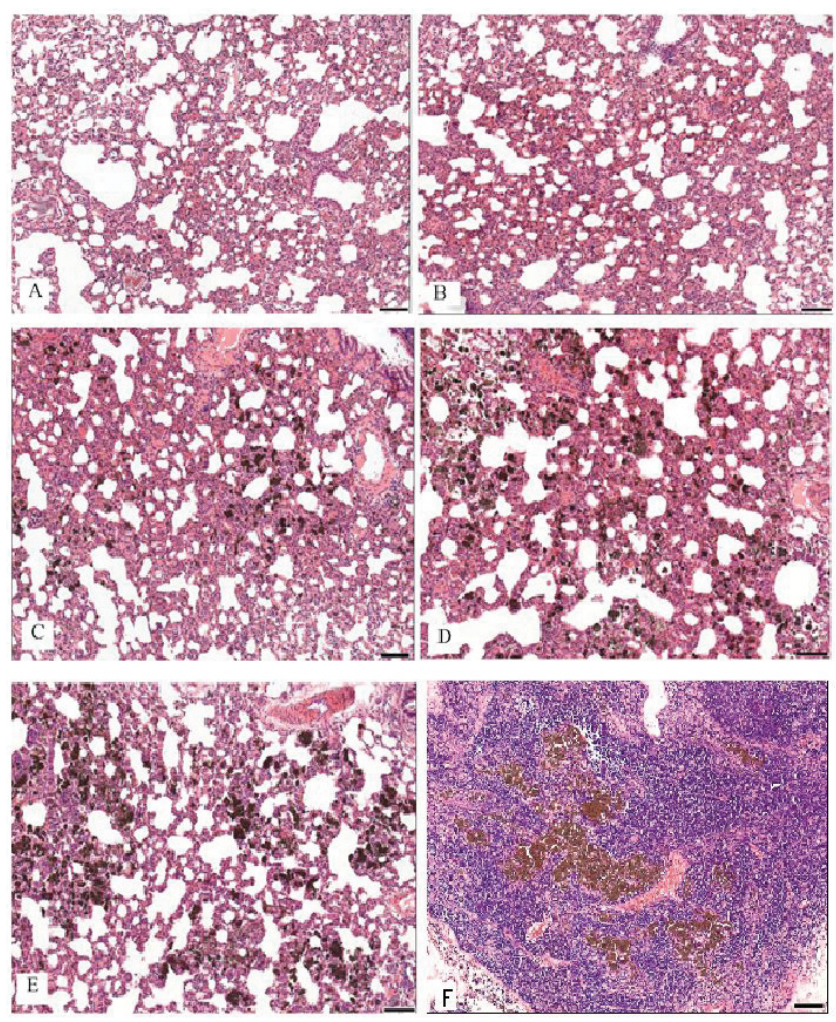

2. ábra
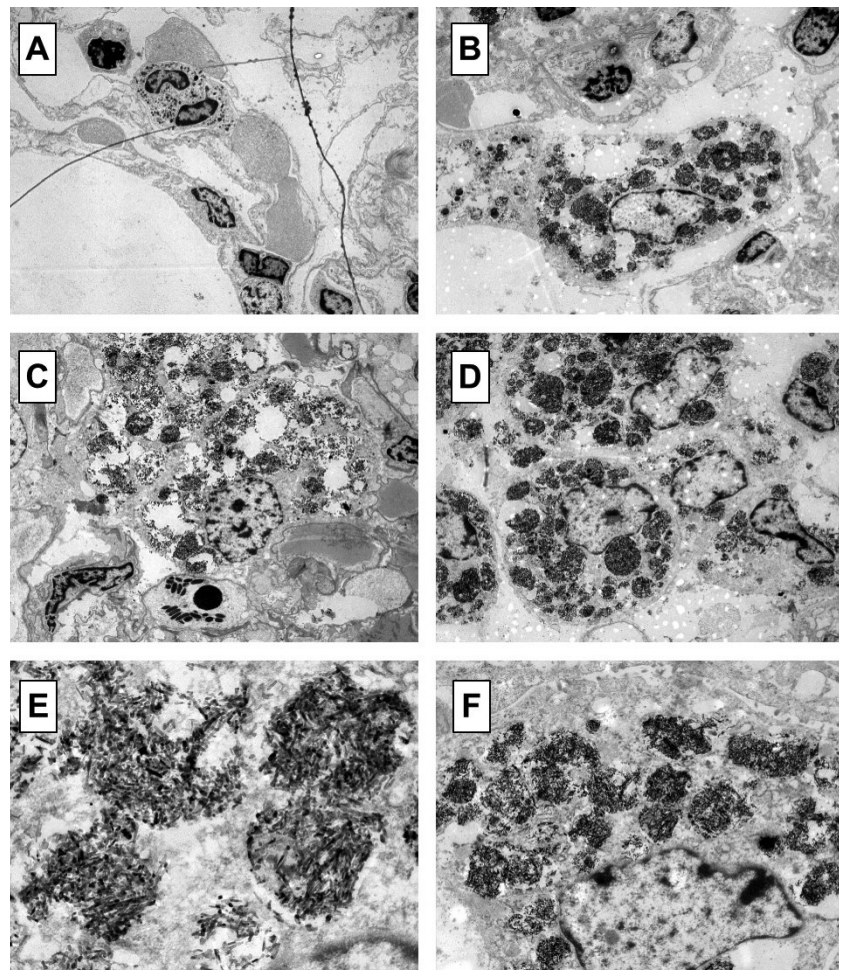

3. ábra

A vivőanyagos kontroll- és a $\mathrm{TiO}_{2}$-NP-kezelt állatok $\mathrm{HE}$-festett tüdőszövetmetszeteinek elektronmikroszkópos felvétele: A: kontroll (ép phagocyta), B: kis dózis (ép és NP-okkal telített phagocyta), C: közepes dózis (NP-ok phagocytán belül és szabadon az alveolaris térben), D: nagy dózis (NP-okkal telített phagosomák a falósejtben), E: nagy dózis (pálcikaszerú NP-ok a phagosomában), F: nagy dózis (NP-okkal telített phagocyta a regionális nyirokcsomóból). Nagyítás: A-D: $2000 \times$, E: $20000 \times$, F: $6000 \times$

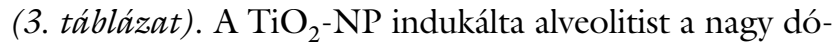
zissal kezelt patkányok tüdőszövetében mért CINCl kemokin, ILl $\alpha$ és L-szelektin inflammatoricus citokinek fokozott expressziója szintén megerősítette. A lokális akut gyulladás krónikussá válását az interstitium ödémás megvastagodása, macrophag- és lymphocytainfiltrációja, ugyanakkor az alveolaris tér csökkenése (2/E ábra), továbbá a VEGF fehérje expressziójának fokozódása jelezte. $\mathrm{Az}$ interstitium legfontosabb sejttípusa a fibroblast, mely az alveolusok kialakulásához és architektúrájuk kialakításához szükséges. A ROS-függő károsodás (például nukleinsav-oxidáció) a fibroblastokban szerepet játszhat az emphysema kialakulásában [29]. A $15 \times 65 \mathrm{~nm}$ nagyságú $\mathrm{TiO}_{2}$-NP-oknak a primer célszervből az alveolaris epithel barrieren keresztül más szövetek felé történő átjutását igazolják a tüdő hilusi nyirokcsomóiban kimutatható ép/töredezett, pálcika alakú, illetve aggregálódott NP-okkal telt phagocyták (2/F és $3 / F$ ábra), továbbá a vér- (és feltételezhetően a nyirok-) keringéssel távolabbi szervekbe kerülést és ott a primer célszervhez hasonló, lokális gyulladásos folyamatok indukálását feltételezi a vesék relatív szervtömegének növekedése is (nem látható adat).

A kezelt állatok tüdőszövetében erőteljes oxidatív stressz volt detektálható (4. táblázat). A tiobarbiturátre- 


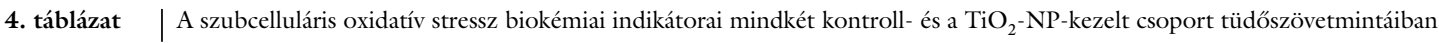

\begin{tabular}{llll}
\hline Csoportok & Intratrachealis kezelések & TBARS $(\mu \mathrm{M} \mathrm{MDA} / \mathrm{mg}$ fehérje $)$ & Katalázaktivitás $(\mathrm{BU} / \mathrm{mg}$ fehérje $)$ \\
\hline Kontroll & $0,9 \mathrm{NaCl}$ & $1,0389 \pm 0,3149$ & $0,00238 \pm 0,00034$ \\
\hline Vivőanyagos kontroll & $1 \% \mathrm{PAA}$ & $1,0783 \pm 0,3325$ & $0,00214 \pm 0,00049$ \\
\hline Kis dózis & $5 \mathrm{mg} / \mathrm{ttkg} \mathrm{TiO}{ }^{-} \mathrm{NP}$ & $1,0250 \pm 0,3855$ & $0,00334 \pm 0,00078^{* * \# \#}$ \\
\hline Közepes dózis & $10 \mathrm{mg} / \mathrm{ttkg} \mathrm{TiO}{ }_{2}-\mathrm{NP}$ & $0,9869 \pm 0,3736$ & $0,00213 \pm 0,00095$ \\
\hline Nagy dózis & $18 \mathrm{mg} / \mathrm{ttkg} \mathrm{TiO}{ }_{2}-\mathrm{NP}$ & $1,2985 \pm 0,3890^{*}$ & $0,00345 \pm 0,00105^{* * \# \#}$ \\
\hline
\end{tabular}

Átlag \pm szórás, $\mathrm{n}=10$

* $,{ }^{* *} \mathrm{p}<0,05 ; 0,01$ vs. kontroll

$\#$ \# $<0,01$ vs. vivőanyagos kontroll

$\mathrm{BU}=$ Bergmayer-egység; $\mathrm{n}=$ állatszám/csoport; $\mathrm{MDA}=$ malondialdehid; $\mathrm{PAA}=$ poliakrilsav; $\mathrm{TBARS}=$ tiobarbiturátreaktív anyag; TiO 2 - $\mathrm{NP}=$ titán-dioxid-nanorészecske

akció erőssége a lipidek oxidatív károsodását, a katalázaktivitás pedig a sejtek fokozott antioxidatív védekezését jellemzi a lokális ROS-túlprodukció hatására. Az oxidatív szabad gyökök fokozott termelődése és akkumulációja a NP-oknak részben a környező vizes közeggel, részben a sejtfelszíni és (a részecskék internalizálódását követően) sejten belüli receptorokkal való kölcsönhatásának következménye [3]. Ismert, hogy intracellulárisan a NP-ok hajlamosak a mitokondriumok múködésének megzavarásával oxidatív szabad gyökök keletkezését indukálni [30]. Celluláris szinten a ROS-túltermelődés károsítja a legfontosabb sejtalkotókat, így a foszfolipideket, melyek a biológiai membránok alkotóelemei. Ezek funkciózavara más celluláris kompartmentek, például emzimek és/vagy membránok diszfunkcióját okozhatja. Irodalmi adatok támasztják alá, hogy a lipidperoxidációs károsodás szerepet játszik különböző oxidatív stresszel összefüggő krónikus nem légzőszervi (például arteriosclerosis, egyes cardiovascularis és emésztőszervi) és pulmonalis (például asztma, cystás fibrosis vagy interstitialis tüdőbetegség) kórképek patogenezisében [31, 32], illetve a mitokondriummúködés zavara összefüggésben áll például a COPD kialakulásával [29]. Az eddigi vizsgálatok azt is alátámasztják, hogy a NP-ok primer lokális hatása mellett számolni kell szisztémás, reaktív szabad gyök termelésére, thrombocytaaggregációra gyakorolt hatással is, amely növeli a cardiovascularis vagy egyes degeneratív központi idegrendszeri betegségek rizikóját is [6, 30].

A 28 napos intratrachealis instillatio és az észlelt szervspecifikus hatások közötti összefüggés statisztikai vizsgálatának eredménye megerősítette a kezelt állatok (kis, közepes és nagy dózisú csoport) tüdőinek tömege, Ti-tartalma és a lipidperoxidáció mértéke közötti korrelációt (4. ábra).

\section{Megbeszélés}

A kapott eredmények alátámasztják azt - a humánexpozíció következményei [15] által sejtetett - összefüggést, miszerint a $\mathrm{TiO}_{2}$-NP-okkal történő légúti expozíció mind akut, mind krónikus lokális gyulladást hozhat létre a primer célszervben/szövetben. Ennek a - tipikusan foglalkozási - kockázatnak a fennállását modellszámításokkal is igazolták [33]. Patkányban $\mathrm{TiO}_{2}-\mathrm{NP}$ intratrachealis instillatiója fokozta a tranzitórikus és a perzisztáló gyulladásos, illetve allergiás reakciók kialakulását [34] mindezek értelmében az inhalált NP-ok szerepet játszhatnak a tüdőt és más szerveket érintő, krónikus fibrosissal járó elváltozások kialakulásában és progressziójában [35]. Más szervek érintettségét a NP-ok szervezeten belüli nagyfokú mozgékonysága [3] magyarázza, ugyan-
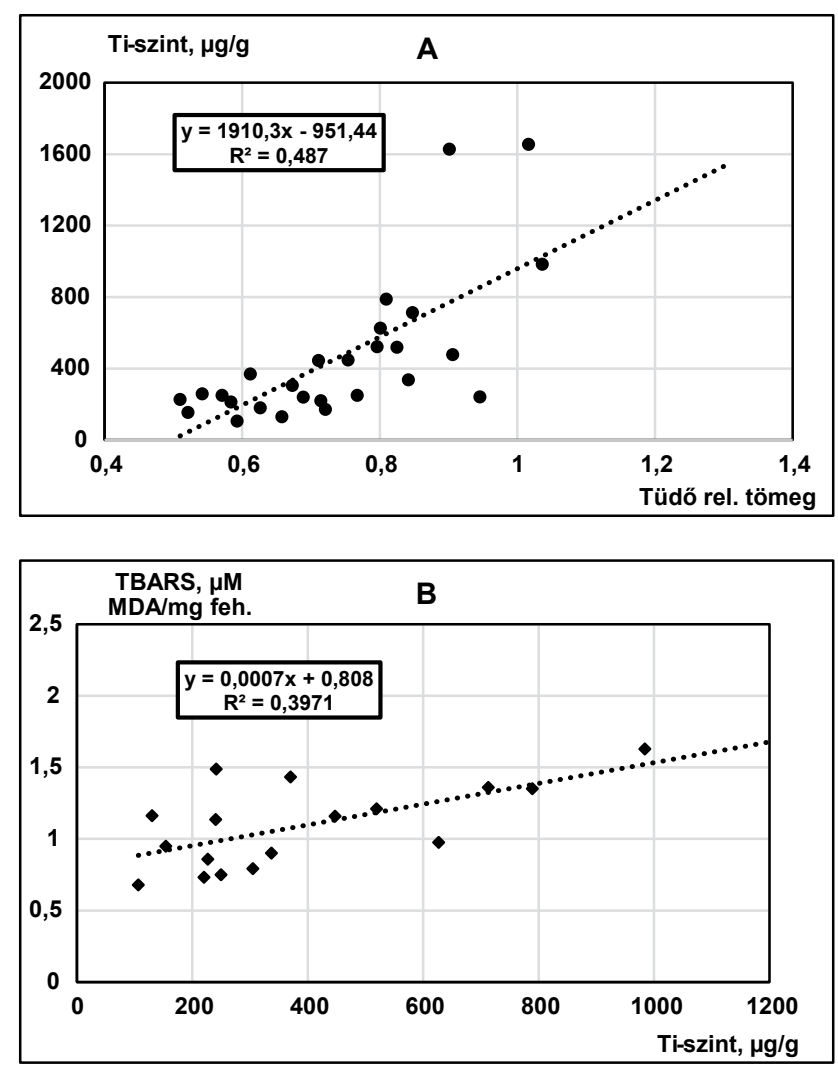

\begin{tabular}{l|l} 
4. ábra & Korreláció a kezelt állatok tüdőmintáinak Ti-szintje és a relatív
\end{tabular} tüdőtömeg (A), illetve a tüdőszövetben kimutatott - celluláris oxidatív stresszre utaló - malondialdehid (MDA)-koncentráció között (B) 
is a barriereken (pulmonalis, vér-agy gát, placenta) átjutva és a szisztémás keringésbe kerülve más, távolabbi szervekbe (máj, vese, szív, agy) kerülhetnek, és ott - a tüdőszövet károsodásához hasonlóan - gyulladásos mediátorok megjelenésén keresztül zavarhatják meg azok múködését. A vér-agy gát károsodása fő rizikótényezője lehet például a DNS-mutáción, oxidatív károsodáson és inflammatoricus citokinek megjelenésén alapuló, továbbá a membrántranszporterek múködészavarának, mely krónikus neurodegeneratív betegségek (például Alzheimer-kór) kialakulásához vezethet [36]. Irodalmi adatok igazolják az immunrendszer múködésének NP indukálta károsodását [37].

A kezelt patkányokban létrejött belső expozíciót a tüdőszövet Ti-tartalmának kémiai kimutatásával és a nanopálcikák jelenlétének közvetlen, elektronmikroszkópos felvételével is igazoltuk. Az általunk alkalmazott $\mathrm{TiO}_{2}{ }^{-}$ nanopálcikák kristályformája anatáz volt - ez a kémiailag aktívabb változat [38], és ezzel összhangban határozottan fokozódott a kezelt állatok tüdőszövetében az oxidatív stressz (4. táblázat). A TEM-képek tanúsága szerint a sejtekbe került $\mathrm{TiO}_{2}$-NP-ok többnyire multivesicularis testekben, illetve phagosomákban találhatók, ami az autophagia beindulását jelezheti. Ez az önmagában véve fiziológiás folyamat a $\mathrm{TiO}_{2}$-NP-ok patomechanizmusának egyik elemeként szerepelhet [39], mivel a lysosomák enzimei a $\mathrm{TiO}_{2}$ - (és más szervetlen) anyagú NP-okat nem bontják le. A NP-okkal terhelt phago-, illetve phagolysosomák felhalmozódnak a sejtben, normális feldolgozásuk elakad. A lysosomák közvetlenül is károsodnak a NP-ok által [18], és megsérülő membránjukon át - amiben a tiobarbiturátreakció által jelzett (4. táblázat) lipidperoxidációnak is szerepe lehet - olyan faktorok, például katepszin-B, jutnak ki a citoplazmába, melyek citokinek aktivációját idézik elő, és végül sejtpusztuláshoz vezetnek (ezt többek közt humán alveolaris eredetű sejtvonalon is bizonyították [40]). A patológiás folyamatban a lokális gyulladás elsődleges szerepét/jelenlétét igazolják az intracelluláris 'multiplex citokin fehérje assay' eredményei is. A NP indukálta reaktívszabadgyök-felszabadulás, az oxidatív stressz és a következményes szöveti hypoxia akut gyulladásos folyamatokat indukál, melyek indikátora például a macrophagfelszaporodás és az aktivált macrophagok által termelt (pro)inflammatoricus citokin (adheziós, kemokin, proangiogén) proteinek expressziójának fokozódása. Irodalmi adatok szerint a nano- $\mathrm{TiO}_{2}$ egyetlen instillatiója $(3,3 \mathrm{mg} / \mathrm{ttkg}$ [4l]) patkányok tüdejében 1 hónapig tartó, a kemokinek felszaporodásával és NP-okkal telített macrophagok megjelenésével járó gyulladásos reakciót idézett elő, mely utóbbi hatás hasonló volt az általunk megfigyelthez (1. ábra). A VEGF proangiogén protein overexpressziója a lokális folyamat akut szisztémás gyulladásba történő átmenetét feltételezi, mely alapját képezheti fibroticus folyamatok kialakulásának. Igazolták, hogy az ILl a lokálisan aktiválja a vascularis endotheliumot és a lymphocytákat, így lokális szöveti destrukciót okoz. Az endothelsejt-károso- dás biomarkere a L-szelektin adhéziós molekula - mely expressziója fokozott volt a nagy dózisú $\mathrm{TiO}_{2}$-NP-kezelt csoportban. Az angiogenezisben a CXC-kemokineknek jelentős szerepük van. Kísérletünkben a CXCL5-citokintermelés növekedését tapasztaltuk a nagy dózist kapott csoportban, ami a lokális krónikus gyulladás akut szisztémás gyulladásba történő átmenetére utal.

Az exponált munkásokban [14] kimutatott csökkent $\mathrm{FEV}_{1.0}$ és más tünetek (például köpetürítés) COPD-szerü elváltozásra utalnak. A COPD patomechanizmusában valószínúleg szerepet kapnak a veleszületett immunrendszer részét alkotó inflammasomák [42], melyek aktiválódásában több, a szövetbe került NP-ok által is tipikusan kiváltott folyamat, például oxidatív stressz és lysosomakárosodás vesz részt [43]. $\mathrm{Nano}-\mathrm{TiO}_{2}$ adagolásával emberi és egéreredetű macrophagokban in vitro az Nlrp3 inflammasomák aktiválását és ILl $a$ és - $\beta$ termelődését lehetett kiváltani, egerek intranasalis nano- $\mathrm{TiO}_{2}-$ kezelésével pedig a folyamat in vivo analógja, ILla-függő tüdőbeli gyulladás volt előidézhető [44]. Állatmodellben kialakított allergiás légúti gyulladás nano- $\mathrm{TiO}_{2}$ adására fellépő súlyosbodását, valamint az asztmás betegek kilégzési csúcsáramlási (PEF) értékkel jellemzett aktuális állapota és a lakóhelyi levegő ultrafinom (azaz nano-) részecskeszám-koncentrációja közötti negatív korreláció fennállását más irodalmi adatok is alátámasztják $[37,45]$.

\section{Következtetés}

Eredményeink és az irodalmi adatok összevetése alapján kimondható, hogy a belélegzett $15 \times 65$ nm nagyságú, pálcika alakú $\mathrm{TiO}_{2}$-nanorészecskék oki tényezőként szerepelhetnek ROS indukálta oxidatív stressztől függő idült légúti gyulladásos (COPD-szerü, emphysemás), valamint nem légúti betegségek kialakulásában és/vagy progressziójában, és ennek során jelentősége van az autophagiának és az immunrendszer múködésében beálló változásoknak. A lokális akut és szubkrónikus gyulladásos reakciók kialakulásában a pálcika alakú $\mathrm{TiO}_{2}-\mathrm{NP}$-ok mérettartománya (elsősorban szélessége és átmérője) és expozíciós dózisa lényegesnek bizonyult. Ebből következően indokolt a légúti és dermalis expozíció potenciális veszélye esetén hatékonyabb munkavédelmi rendszabályokat biztosítani, továbbá nemzetközileg már megállapított határértékeket bevezetni a nano- $\mathrm{TiO}_{2}$-expozíció kockázatának kitett dolgozók munkahelyein.

Anyagi támogatás: A kutatómunka részben a GINOP 2.3.2-15-2016-00038. sz. pályázat anyagi támogatásával történt.

Szerzôi munkamegosztás: H. T.: Állatkísérletes munka, általános toxikológiai adatok felvétele és értékelése, statisztikai elemzés, a kézirat megszövegezése. P. A., V. T.: A vizsgálati koncepció kialakítása, az adatok összesítő ér- 
tékelése, a kézirat korrekciója. I. N., T. V.: Biokémiai mérések. K. M.: A biokémiai mérések értékelése, a kézirat korrekciója. K. G.: Nanorészecskék előállítása és jellemzése. T. L.: Fénymikroszkópia. R. Zs.: Elektronmikroszkópia. A cikk végleges változatát valamennyi szerző elolvasta és jóváhagyta.

\section{Érdekeltségek: A szerzőknek nincsenek érdekeltségeik.}

\section{Köszönetnyilvánítás}

A szerzők köszönettel tartoznak Dr. Galbács Gábor tanszékvezetó egyetemi tanárnak és munkatársainak (SZTE TTIK Szervetlen és Analitikai Kémiai Tanszék) a szöveti Ti-szintek mérési eredményeiért.

\section{Irodalom}

[1] Buzea C, Pacheco II, Robbie K. Nanomaterials and nanoparticles: sources and toxicity. Biointerphases 2007; 2: MR17-MR71

[2] Keller AA, McFerran S, Lazareva A, et al. Global life cycle releases of engineered nanomaterials. J Nanopart Res. 2013; 15: 1692.

[3] Oberdörster G, Oberdörster E, Oberdörster J. Nanotoxicology: an emerging discipline evolving from studies of ultrafine particles. Environ Health Perspect. 2005; 113: 823-839.

[4] European Agency for Safety and Health at Work. Expert forecast on emerging chemical risks related to occupational safety and health. Office for Official Publications of the European Communities, Luxembourg, 2009.

[5] Kreyling WG, Semmler-Behnke M, Möller W. Health implications of nanoparticles. J Nanoparticle Res. 2006; 8: 543-562.

[6] Pándics T. Clinical application of nanoparticles, and their possible health risk. [A nanorészecskék klinikai alkalmazási lehetőségei és lehetséges veszélyei.] Orv Hetil. 2008; 149: 1785-1790. [Hungarian]

[7] Shi H, Magaye R, Castranova V, et al. Titanium dioxide nanoparticles: a review of current toxicological data. Part Fibre Toxicol. 2013; 10: 15

[8] Chen J, Poon CS. Photocatalytic construction and building materials: from fundamentals to applications. Building Environ. 2009; 44: 1899-1906.

[9] Shakeel M, Jabeen F, Shabbir S, et al. Toxicity of nano-titanium dioxide $\left(\mathrm{TiO}_{2}-\mathrm{NP}\right)$ through various routes of exposure: a review. Biol Trace Elem Res. 2016; 172: 1-36.

[10] Liao CM, Chiang YH, Chio CP. Model-based assessment for human inhalation exposure risk to airborne nano/fine titanium dioxide particles. Sci Total Environ. 2008; 407: 165-177.

[11] Boffetta P, Gaborieau V, Nadon L, et al. Exposure to titanium dioxide and risk of lung cancer in a population-based study from Montreal. Scand J Work Environ Health 2001; 27: 227-232.

[12] Hext PM, Tomenson JA, Thompson P. Titanium dioxide: inhalation toxicology and epidemiology. Ann Occup Hyg. 2005; 49: $461-472$.

[13] Lee KP, Trochimowicz HJ, Reinhardt CF. Pulmonary response of rats exposed to titanium dioxide $\left(\mathrm{TiO}_{2}\right)$ by inhalation for two years. Toxicol Appl Pharmacol. 1985; 79: 179-192.

[14] Garabant DH, Fine LJ, Oliver C, et al. Abnormalities of pulmonary function and pleural disease among titanium metal production workers. Scand J Work Environ Health 1987; 13: 47-51.

[15] Kwon S, Yang YS, Yang HS, et al. Nasal and pulmonary toxicity of titanium dioxide nanoparticles in rats. Toxicol Res. 2012; 28: 217-224.

[16] Noël A, Charbonneau M, Cloutier Y, et al. Rat pulmonary responses to inhaled nano- $\mathrm{TiO}_{2}$ : effect of primary particle size and agglomeration state. Part Fibre Toxicol. 2013; 10: 48.
[17] Orosz L, Papanicolaou EG, Seprényi G, et al. IL-17A and IL17F induce autophagy in RAW 264.7 macrophages. Biomed Pharmacother. 2016; 77: 129-134.

[18] Stern ST, Adiseshaiah PP, Crist RM. Autophagy and lysosomal dysfunction as emerging mechanisms of nanomaterial toxicity. Part Fibre Toxicol. 2012; 9: 20.

[19] Wang Y, Yao C, Ding L, et al. Enhancement of the immune func tion by titanium dioxide nanorods and their application in cancer immunotherapy. J Biomed Nanotechnol. 2017; 13: 367-380.

[20] Kulkarni M, Mazare A, Gongadze E, et al. Titanium nanostructures for biomedical applications. Nanotechnology 2015; 26: 062002.

[21] Dastjerdi R, Montazer M. A review on the application of inorganic nano-structured materials in the modification of textiles: focus on anti-microbial properties. Colloids Surf B Biointerfaces 2010; 79: 5-18.

[22] Murphy FA, Schinwald A, Poland CA, et al. The mechanism of pleural inflammation by long carbon nanotubes: interaction of long fibres with macrophages stimulates them to amplify proinflammatory responses in mesothelial cells. Part Fibre Toxicol. 2012;9: 8

[23] Oszlánczi G, Horváth E, Szabó A, et al. Subacute exposure of rats by metal oxide nanoparticles through the airways: general toxicity and neuro-functional effects. Acta Biol Szeged. 2010; 54: 165-170.

[24] Kálomista I, Kéri A, Galbács G. On the applicability and performance of the single particle ICP-MS nano dispersion characterization method in cases complicated by spectral interferences. $J$ Anal At Spectrom. 2016; 31: 1112-1122.

[25] Beauchemin D. Inductively coupled plasma mass spectometry, methods. In: Lindon J, Tranter GE, Koppenaal G. (eds.) Encyclopedia of spectroscopy and spectrometry (3rd edn.). Academic Press, Oxford, 2016; pp. 236-245.

[26] Serbinova E, Khwaja S, Reznick AZ, et al. Thioctic acid protects against ischemia-reperfusion injury in the isolated perfused Langendorff heart. Free Radic Res Commun. 1992; 17: 49-58.

[27] Beers RF Jr, Sizer IW. Catalase assay with special reference to manometric methods. Science 1953; 117: 710-712.

[28] Schneider CA, Rasband WS, Eliceiri KW. NIH Image to Image J: 25 years of image analysis. Nat Methods 2012; 9: 671-675.

[29] Białas AJ, Sitarek P, Miłkowska-Dymanowska J, et al. The role of mitochondria and oxidative/antioxidative imbalance in pathobiology of chronic obstructive pulmonary disease. Oxid Med Cell Longev. 2016; 2016: 7808576.

[30] Migliore L, Uboldi C, Di Bucchianico S, et al. Nanomaterials and neurodegeneration. Environ Mol Mutagen. 2015; 56: 149170 .

[31] Calenic B, Miricescu D, Greabu M, et al. Oxidative stress and volatile organic compounds: interplay in pulmonary, cardio-vascular, digestive tract systems and cancer. Open Chem. 2015; 13: 1020-1030.

[32] Domej W, Oettl K, Renner W. Oxidative stress and free radicals in COPD - implications and relevance for treatment. Int J Chron Obstruct Pulmon Dis. 2014; 9: 1207-1224.

[33] Ling MP, Chio CP, Chou WC, et al. Assessing the potential exposure risk and control for airborne titanium dioxide and carbon black nanoparticles in the workplace. Environ Sci Pollut Res Int. 2011; 18: 877-889.

[34] Oyabu T, Morimoto Y, Hirohashi M, et al. Dose-dependent pulmonary response of well-dispersed titanium dioxide nanoparticles following intratracheal instillation. J Nanopart Res. 2013; 15: 1600 .

[35] Morimoto Y, Izumi H, Kuroda E. Significance of persistent inflammation in respiratory disorders induced by nanoparticles. $\mathrm{J}$ Immunol Res. 2014; 2014: 962871.

[36] Erdő F, Hutka B, Dénes L. Function, aging and dysfunction of blood-brain barrier. Crossing the barrier. [A vér-agy gát 
múködése, öregedése és diszfunkciója. Átjutás a barrieren.] Orv Hetil. 2016; 157: 2019-2027. [Hungarian]

[37] Thompson EA, Sayers BC, Glista-Baker EE, et al. Innate immune responses to nanoparticle exposure in the lung. J Environ Immunol Toxicol. 2014; 1: 150-156.

[38] Sayes CM, Wahi R, Kurian PA, et al. Correlating nanoscale titania structure with toxicity: a cytotoxicity and inflammatory response study with human dermal fibroblasts and human lung epithelial cells. Toxicol Sci. 2006; 92: 174-185.

[39] Cohignac V, Landry MJ, Boczkowski J, et al. Autophagy as a possible underlying mechanism of nanomaterial toxicity. Nanomaterials $2014 ; 4$ : 548-582.

[40] Boland S, Hussain S, Baeza-Squiban A. Carbon black and titanium dioxide nanoparticles induce distinct molecular mechanisms of toxicity. WIREs Nanomed Nanobiotechnol. 2014; 6: 641-652.

[41] Yoshiura Y, Izumi H, Oyabu T, et al. Pulmonary toxicity of welldispersed titanium dioxide nanoparticles following intratracheal instillation. J Nanopart Res. 2015; 17: 241.
[42] Caramori G, Adcock IM, Di Stefano A, et al. Cytokine inhibition in the treatment of COPD. Int J Chron Obstruct Pulmon Dis. 2014; 9: 397-412.

[43] Farrera C, Fadeel B. It takes two to tango: understanding the interactions between engineered nanomaterials and the immune system. Eur J Pharm Biopharm. 2015; 95: 3-12.

[44] Yazdi AS, Guarda G, Riteau N, et al. Nanoparticles activate the NLR pyrin domain containing 3 (Nlrp3) inflammasome and cause pulmonary inflammation through release of IL- $1 \alpha$ and IL13. Proc Natl Acad Sci USA 2010; 107: 19449-19454.

[45] Penttinen P, Timonen KL, Tiittanen P, et al. Ultrafine particles in urban air and respiratory health among adult asthmatics. Eur Respir J. 2001; 17: 428-435.

(Horváth Tamara, Szeged, Dóm tér 10., 6720 e-mail: horvath.tamara@med.u-szeged.hu)

\section{Felhívás és értesítő}

\section{magyar egészségügyi dolgozók (orvos, fogorvos, gyógyszerész, tudományos kutató, ápoló, asszisztens, gyógytornász, egyéb szakdolgozó, szociális munkás, stb.) részére}

\section{Nemzetközi orvos-muzsikus koncert 2019. május 11. - Tihany, Müvelödési ház Jelentkezési határidő: 2019. január 31.}

További információ és komplett jelentkezési anyag a palotas@asklepios-med.eu e-mail címen kérhető.

Bármilyen előadói tevékenység bemutatható (hangszeren játszás, ének, tánc, szóló vagy több tagú együttes fellépése, stb.). Semmiféle „szelekció” vagy „cenzúra” nincs.

A koncert non-profit módon kerül megrendezésre: teljesen téritésmentes a részvétel, azaz mind a fellépés, mind pedig a közönség soraiban történő megjelenés mindenki számára ingyenes.

A világ minden tájáról várunk müvész kollégákat, így lehetőség nyílik hazai és külföldi orvosokkal, egészségügyi dolgozókkal szakmai, valamint kulturális kapcsolat felvételére is.

Nagy tisztelettel kérem, hogy kollégái, ismerősei körében legyen kedves terjeszteni a zenei esemény hírét, hogy minél többen vehessünk részt ezen a nemében egyedülálló nemzetközi rendezvénysorozaton, mind fellépöként, mind pedig vendégként.

Együttmüködésüket, valamint a rendezvényen való részvételüket elöre is köszönöm.

Üdvözlettel:

Prof. Dr. Palotás András

alapító és vezető

Asklepios-Med (www.asklepios-med.eu)

Telefon: +36 (30) 255-6225

E-mail: palotas@asklepios-med.eu

H-6722 Szeged, Kossuth Lajos sgt. 23.

A cikk a Creative Commons Attribution 4.0 International License (https://creativecommons.org/licenses/by/4.0/) feltételei szerint publikált Open Access közlemény. (SID_1) 